\title{
Requirements of Net Generation towards university libraries in Sri Lanka
}

Mashroofa, M. M ${ }^{1}$

\begin{abstract}
At present academic libraries have a trend to introduce innovative services in par with developing technologies as well as the different aspirations of Net Generation. This study aims to explore the characteristics of Net Generation, their help seeking preferences, information behaviours and their needs and wants towards university library. A survey of freshmen was conducted in 2011 at University of Jaffna, Eastern University and South Eastern University of Sri Lanka. Qualitative and quantitative approaches were carried out. The study found that majority of respondents use internet but they rarely use library web pages and Online Public Access catalogue (OPAC). They have a tendency to move to e-resources and they prefer multimedia information than textual information. They are comfortable in asking help from librarian directly (in- person communication) whilst some of them wish to communicate via e-mail, face book and instant messaging. It recommends that librarians can help students via help-desk, instant messaging, e-mail, chat or ask a librarian services from the library websites. Libraries should initiate action to collect more electronic resources. Information literacy should be included as a course unit.
\end{abstract}

Key words: Net Generation, Millennials, Library instruction, information common, information behaviour.

\section{Introduction}

With the evolution of information and communication technology and invention and use of many kinds of digital devices information behaviours and preferences of library patrons have become different from their predecessors. This is a great challenge for librarians of today. Academic library is considered as 'heart of the university' thus it has to play major role in supporting teaching, learning, research and development of the university. While

\footnotetext{
${ }^{1}$ Senior Assistant Librarian, South Eastern University of Sri Lanka. Email: mashroof@seu.ac.lk
} 
Journal of the University Librarians Association, Sri Lanka, Vol. 16, Issue 2, July 2012

libraries are providing conventional services they have to introduce innovative services to meet the information needs of users. Before initiating any such services it is important to identify the characteristics of the library users and their requirements. The three universities under this study are located in the northern and eastern provinces of Sri Lanka which was under threshold of war for last 2-3 decades. Though there were many disturbances during war time these universities thrived to serve at their maximum level. Libraries of these universities also highly supported their respective universities. However it is important to their information behaviours, characteristics of the students and their requirements towards library. As this is the generation of digital learners their information seeking habits and learning styles are different from their parents.

\section{Significance of the Study}

As this is the generation of digital natives their behaviours of information and learning styles are different. The intellectual, social, motivational and emotional needs of Net Generation are investigated widely by many researchers. Meanwhile, it is important to explore the information behaviours and the needs and wants of undergraduates especially the freshmen. It is important to explore whether these university libraries are currently equipped to meet the needs of this new cohort of students. University libraries must cope with the growing demand of Net generation in collection and access services.

Mi and Nesta (2006) stated that libraries are losing their role as "primary information providers" as users turn to search engines as their starting point of research. In business terms market shares of libraries are eroding. So, it is a crucial role of academic librarians to identify the characteristics of the library users', their information behaviours and help seeking preferences in order to serve them very effectively and efficiently.

\section{Literature Review}

\section{Diversity of Generations}

Net Generation (NG) is defined by different authors in different manners considering their birth years and some specific characteristics and habits. Howe and Strauss (2000) 
Journal of the University Librarians Association, Sri Lanka, Vol. 16, Issue 2, July 2012

defined NG as those who were born around the time when PC was introduced. This is approximately those who were born between 1982-2000. They sent their first freshmen to college in 2000. According to Oblinger and Oblinger (2005) NG were born in between 1982-1991.

The diversity of generations by Oblinger and Oblinger (2005) should be considered because this classification has been widely accepted all over the world and adopted by many scholars for several studies. Accordingly generations are classified as; Matures (people who born in 1900-1946 are described as "Greatest Generation. They have the attributes of command and control as well as self-sacrifice. They respect for authority, prefer family and community involvement. They dislike technology ), Baby Boomers (people who born in 1946-1964 are described as" Me Generation". They are characterized as optimistic and workaholic. They like to have responsibility and they are work ethic. They have the attitude "can-do". They dislike laziness), Generation X (People who born in 1965-1982 are described as "Latchkey Generation". They are independent and sceptical. They like freedom and capable of multitasking. They balance the work and life. They dislike red tape; that means formalities or rules and regulation and Hype propaganda/publicity), Net Generation (people who born in 1982-1991 and they are described as "Millennial". They are characterized as hopeful and determined. They like public activism and latest technology. They are very close with their parents. They dislike anything slow and negativity and Post-Millennial (people who born in 1995-present).

Many other scholars such as Howe and Strauss(2000), Lancaster and Stillman (2002), Martin and Tulgan (2002), Tapscott (2009) and Zemke et al.(2000) in Berk (2009), have classified generations differently.NG has been differently named by many scholars. These names were given according to some specific characteristics or behaviours of them. The term Net generation is related to inter (net) and related technology with which this generation grew up. Likewise Tapscott (1997) used the term "Nexters" for Net generation. "Digital natives" is the term used by Prensky (2001) considering 'digital' as 
Journal of the University Librarians Association, Sri Lanka, Vol. 16, Issue 2, July 2012

their native language. He justified that their entire lives surrounded by computers, cell phones and other digital devices. "Millennial" (Howe and Strauss, 2000) is the term used as they entered the university in 2000 , i.e in millennium. They are also called as "Trophy generation" or "Trophy kids" because everyone wins and no one loses. They are successors in achieving their goals. (Alsop (2008) and Tulgan(2009). Also they were called as 'echo-boomers', dot. coms etc.

Berk (2009) rejected this by saying "defining by birthdates and labelling any group of people ascribing specific characteristics to them are fraught with problems of misrepresentation and generalization". As far as Sri Lanka is concerned ICT devices become popular around1990s: almost a decade later than the US. Therefore these definitions may not be appropriate and people who were born in and after 1989 can be considered as NG or digital natives. Author of this research paper has given an operational definition for this study as "Children born in and after 1989 in Sri Lanka are considered as NG and they are technologically savvy". According to this definition the undergraduate students (here considered only the freshmen) are aged 18-21. This definition should be tested with the students specifically those who are coming from war zone of Sri Lanka.

\section{Characteristics of NG}

Characteristics of Net generation were studied based on education (teaching, learning), the workplace, and political, social, economical impact. Oblinger and Oblinger (2005) has described the characteristics of Net generation as follows. They are digitally literate: able to use intuitively a variety of IT devices and navigate the internet. They are comfortable using technology without an instruction manual. They are more visually literate. They are capable for multitasking. They are connected: They feel the world has been a connected place. They are very fast. They expect immediate response. They can move one activity to another quickly sometimes performing simultaneously. They value speed than accuracy. They are experimental. Net Genres prefer to learn by doing rather by being told. They are 
Journal of the University Librarians Association, Sri Lanka, Vol. 16, Issue 2, July 2012

social. They prefer to learn in teams. Peer-to-peer approach is common. They are structured. They are very achievement oriented. They work towards the goal.

Many of these characteristics are most commonly observed with the students even if they are coming from developing countries. Location is not a matter. Everywhere technology is rapidly developing. Savage (2003) in Oblinger and Oblinger (2005) has described that for the NG, the internet is like oxygen: they can't imagine being able to live without it.

\section{NG and Libraries}

Library plays major role in academic activities of students such as in writing a paper, assignment or project works, research and lifelong learning process. Nowadays libraries provide new virtual and in-person services to motivate library users to pursue learning and research activities. Lippincott (2005) says as following:

Library can become part of campus life if it is designed with genuine understanding of the needs of (Net Gen) students. This understanding relates not just to the physical facility of the library but to all of the things that a library encompasses: content, access, enduring collections and services and environments to the digital world.

Though academic libraries are adjusting their collection, services and environment to cater the needs of their users, they should identify the major disconnects between libraries and Net Genres.

\section{Information Behaviours of NG}

The most common problem is, these students mainly rely on search engines for information. It has been proven in many studies. OCLC (2006) in Berk (2009) stated that these students use web pages through a search engine for information rather than searching the library website or catalogue. In addition this study found that $89 \%$ of Net Genres begin searches for information with search engines like Google. This is compromise by Lippincott (2005). He has stated that 'libraries rarely provide mechanism 
Journal of the University Librarians Association, Sri Lanka, Vol. 16, Issue 2, July 2012

for information seekers to locate information resources for a particular discipline". He recommends subject specific pathfinders and library guides to assist the users.

\section{Information Common for NG}

Lippincott (2005) stated "Net Geners are opposite of old style formal reference rooms where students were expected to sit straight wooden chairs and work individually and silently without access to technology. Instead, these spaces project comfortable, relaxed environment, a celebration of technology and an invitation to communicate".

This statement is obviously true and at present libraries struggled to facilitate this cohort of students with existing infra structure facilities. He concluded that libraries can offer environment that resonate with NG students while enriching their college education and lifelong learning capabilities. Environment should be conducive to the learners. Information commons are now widely accepted for designing physical spaces. Information commons consists of places for individual study, group work, multimedia production area, computer labs and classrooms with reference services librarians. Usually it is a collaborative effort of library and IT staff.

\section{Net Generation and Reference Services}

Ismail (2009) has conducted a study at Marywood University aiming to identify the requirement of Net generation. The author has focused on reference services specifically on mode of help seeking. She found that research assistance such as chat, face book and course management software are not favourite among 18-22 years old at Mary wood. Instead majority preferred to contact the librarian directly. Also, this study indicated that these students were confident in their ability to locate both electronic and print sources without a librarian's help and library instructions has no impact to access information. However her findings cannot be generalize even for the particular study as she has mentioned she got only $10 \%$ response. On the other hand this finding seems difficult to accept by practicing librarians because dramatically it is true that library instructions support and enhance locating resources and finding information. In addition it contradicts 
Journal of the University Librarians Association, Sri Lanka, Vol. 16, Issue 2, July 2012

the suggestions and finding of some other researchers (Patricia (1999), Oblinger D. ed (2006) Lippincott (2005), Rockman (2004)) who have mentioned that even the students are net savvy or technology savvy they are not information literate and teaching information literacy and library instruction is insisted by practicing librarians, researchers and scholars all over the world. There were no literatures found on NG which is originated from Sri Lanka.

\section{Methodology}

A survey for freshmen students of University of Jaffna, Eastern University, Sri Lanka and South Eastern University of Sri Lanka has been conducted. Questionnaire was used as research instrument. Stratified random sampling technique was used to select sample. Ten percent of the student population was selected as sample. Altogether 220 questionnaires were distributed and 140 were received at a response rate of $63.63 \%$. Students were asked to rate their preferences for a variety of questions. Data was analyzed qualitatively and quantitatively using SPSS statistical software.

\section{Results}

Respondents profile indicates that $48.57 \%$ male students and $51.43 \%$ female students and respondents are from faculty of Arts (54), faculty of Management (40), faculty of Science (22) faculty of Medicine (11), Faculty of Islamic Studies and Arabic Language (7) and Faculty of Agriculture(6). Birth year of 102 (72.9\%) respondents' falls in 1989-1990. Considering the area of residence majority students $53(37.85 \%)$ are coming from rural areas whilst 30 (21.42\%) and 27(19.28\%) are from sub urban and urban area respectively whilst $30(21.42 \%)$ respondents did not mention their area of residence.

\section{Library Visit \& Library Instruction}

The students were asked how often they visit their respective university libraries. Nearly $28 \%$ of them visit the library once a day and others also visit once in a week $(23.57 \%)$, once in two days (15.71\%), often(17.66\%) and once in a fortnight (3.57\%). Very few of them $(5.71 \%)$ do not visit the library and the same counterparts (5.71\%) did not respond 
to this question. Purpose of their library visit has been shown in figure 1 .

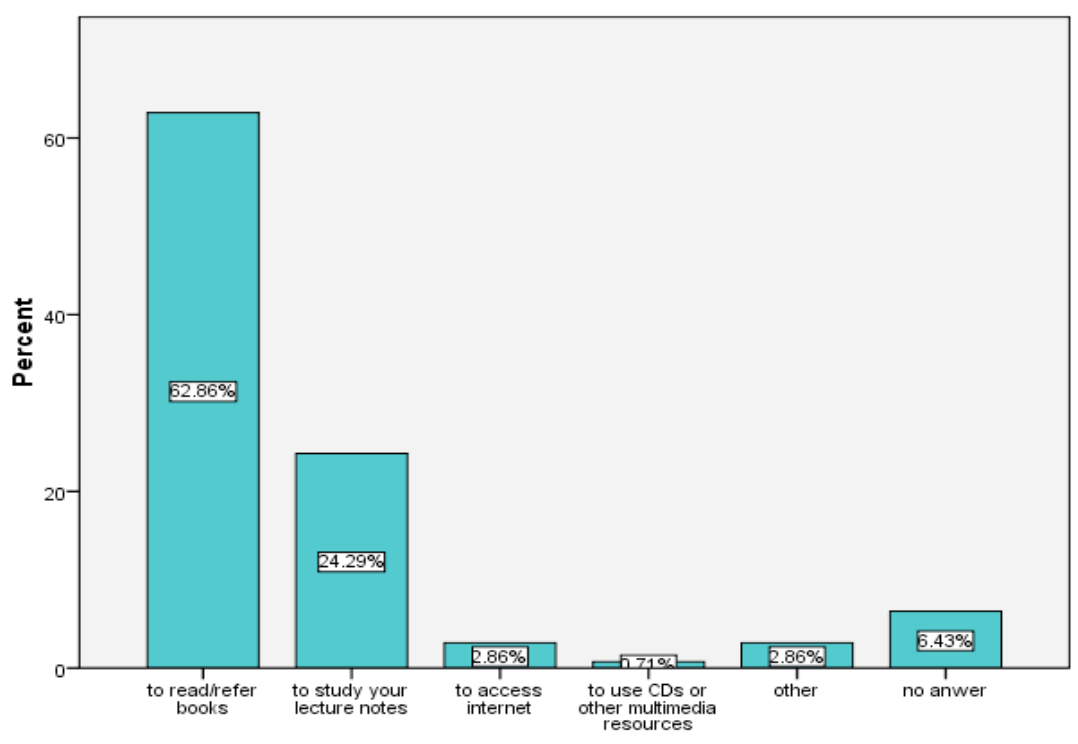

Figure 1: Purpose of library visit

Majority respondents (62.86\%) visit library to read/ refer books while $24.29 \%$ for studying their lecture notes. Very few respondents visit library to access internet (2.86\%) as well as to use CDs or other multimedia resources (1.71\%) respectively. Though these libraries possess electronic resources and other multimedia information tools usage is very poor. This might be due to lack of instruction or unawareness of students. So they have been asked whether they had received any library instruction so far.

The result indicates that $68 \%$ of the freshmen have received library instruction to use their library, library resources and services whilst $23.57 \%$ did not receive. A very few of them ( $8.57 \%$ ) did not respond to this question. Figure 2 indicates how students from each university have responded on library instruction. 


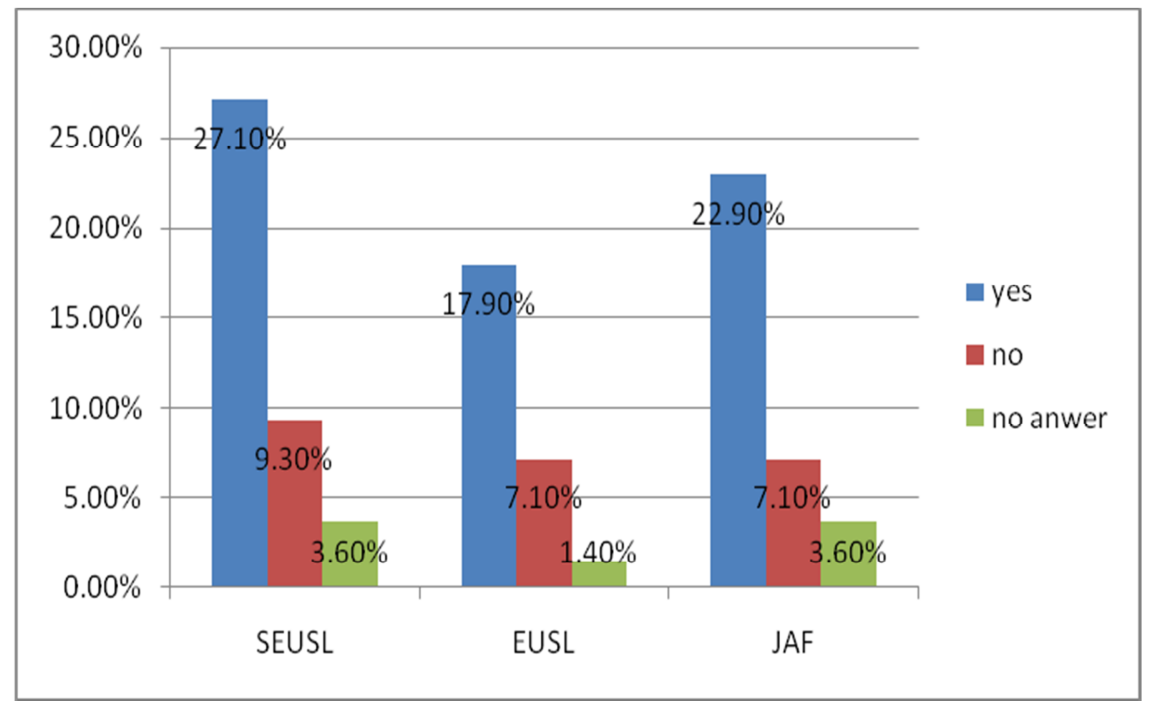

Figure 2: Library Instruction for freshmen by the selected Universities

\section{Librarian's Help and Help Seeking Preferences of Freshmen}

The students were asked if they ever met their librarian, and if they are comfortable in asking for help from the librarian (see table 1). Majority of them have met their librarian and also they are comfortable in asking help from librarian. However a few negative responses indicates that some of them were not comfortable in meeting the librarian. Again they were asked whether they want to establish regular help hours. $64 \%$ of respondents like this attempt while $24 \%$ do not want.

Table 1: Librarians' help and establishing regular help hours

\begin{tabular}{|c|c|c|c|c|}
\hline Description & $\begin{array}{l}\text { Comfortable } \\
\text { Librarian }\end{array}$ & meeting & Evermet Librarian & Regularhelphours \\
\hline Yes & $110(78.6 \%)$ & & $101(72.1 \%)$ & $89(63.6 \%)$ \\
\hline No & $28(20 \%)$ & & $33(23.6 \%)$ & $33(23.6 \%)$ \\
\hline Noanswers & 2(1.4\%) & & $6(4.3 \%)$ & 18(12.9\%) \\
\hline Total & 140 & & 140 & 140 \\
\hline
\end{tabular}


Journal of the University Librarians Association, Sri Lanka, Vol. 16, Issue 2, July 2012

In addition, the students were asked for the preferred modes of seeking help (see table 2 ). Nearly $63 \%$ of the respondents wish to meet librarian directly whilst few others like email, phone, instant messaging and Face - book etc. This finding is similar to Ismail (2009).

Table 2: Mode of help seeking preferences

\begin{tabular}{l|lll}
\hline Description & Frequency & Percent & Valid Percent \\
\hline e-mail communication & 21 & & \\
through facebook & 3 & 15.0 & 15.0 \\
overthephone & 12 & 2.1 & 2.1 \\
instantmessaging & 4 & 8.6 & 8.6 \\
directlymeet librarian & 88 & 2.9 & 2.9 \\
no response & 12 & 62.9 & 62.9 \\
\hline Total & 140 & 8.6 & 8.6 \\
\hline
\end{tabular}

\section{Information Behaviours of Freshmen}

In order to identify the information behaviour of these students their ability and experience in using the Internet were considered first. Among the respondents 106 (75.7\%) have experience in using internet whilst $34(24.3 \%)$ do not have. Among the internet users $104(74.3 \%)$ started to use internet after they are 15 years old and the balance $2(\%)$ have used after coming to the university. When further explored how much time they spend for a day for accessing internet, majority of them 62 (44.3\%) spend less than an hour. Whilst 21 (15\%) use 1-2 hours and only 5 (3.6\%) use 3-5 hours per day. Others did not mention duration of Internet use. 67 (47.9\%) respondents said that they use Internet for learning whilst 71 (50.7\%) do not use Internet for learning purposes. However the purpose of using Internet was further explored. Results are tabulated in Table 3. 
Journal of the University Librarians Association, Sri Lanka, Vol. 16, Issue 2, July 2012

Table 3: Purpose of using internet

\begin{tabular}{l|lll}
\hline Description & Frequency & Percentage & Valid Percent \\
\hline Newinformation & 100 & 71.4 & 71.4 \\
Updateknowledge & 14 & 10.0 & 10.0 \\
Sendand receivee-mails & 5 & 3.6 & 3.6 \\
Chat/video phone & 1 & .7 & .7 \\
Pleasure & 3 & 2.1 & 2.1 \\
\hline
\end{tabular}

Though the result indicates that a very few respondents use internet for sending and receiving e-mail and for pleasure, majority respondents (71.4\%) use internet to get new information.

Students were asked when they want to solve an information problem what is their first approach. Exactly 77 (55\%) students approach the library first whilst $61(43.6 \%)$ of students approach 'web' first. This result contradicts with Mi and Nesta (2006) that now libraries are losing their role as "primary information provider" as users turns to search engines as their starting point to do research.

Further it was explored when they search information from internet how many of them use library web pages and search engines especially Google. Finding here is interesting that nearly $70 \%$ of respondents use Google while only $17.1 \%$ use library webpage and a few of them $5.7 \%$ use other search engines. Though the same sample of students approaches first their libraries to get information when it comes to internet or web search they prefer to search through 'Google'. This result can be compared with the result of OCLC 2006. Results have been tabulated in Table 4. 
Journal of the University Librarians Association, Sri Lanka, Vol. 16, Issue 2, July 2012

Table 4: Access information through library web/ Google/other search engines

\begin{tabular}{l|lll}
\hline Description & Frequency & Percentage & Valid Percent \\
\hline Valid & 2 & 1.4 & 1.4 \\
library webpage & 24 & 17.1 & 17.1 \\
Google & 98 & 70.0 & 70.0 \\
otherSearchengines & 8 & 5.7 & 5.7 \\
noanswer & 8 & 5.7 & 5.7 \\
\hline Total & $\mathbf{1 4 0}$ & $\mathbf{1 0 0 . 0}$ & $\mathbf{1 0 0 . 0}$ \\
\hline
\end{tabular}

This study shows that majority students prefer Google search for information. It is important to investigate their perception towards internet resources. They were asked whether they can find all the information they might ever need on the internet. Nearly $69 \%$ responded 'yes' while $29 \%$ responded 'no'. And others did not respond to this question.

In addition they were asked whether they ever visited library websites for information. Results are shown in table 5.

Table 5: Visit of library web pages

\begin{tabular}{c|llll}
\hline Description & Frequency & Percentage & Valid Percent & $\begin{array}{l}\text { Cumulative } \\
\text { Percent }\end{array}$ \\
\hline Valid & 3 & 2.1 & 2.1 & 2.1 \\
Yes & 54 & 38.6 & 38.6 & 40.7 \\
No & 83 & 59.3 & 59.3 & 100.0 \\
\hline Total & $\mathbf{1 4 0}$ & $\mathbf{1 0 0 . 0}$ & $\mathbf{1 0 0 . 0}$ & \\
\hline
\end{tabular}

Only $38.6 \%$ of the respondents have visited library web page for information. They were asked further whether they have used OPAC/ other database of their respective university libraries. Only (35)25\% of respondents use OPAC while (101) $72.1 \%$ do not use. A very few students 4 (2.9\%) did not respond to this question. 
Journal of the University Librarians Association, Sri Lanka, Vol. 16, Issue 2, July 2012

Using web 2 or library 2 of present day students is widely spoken and web 2.0 is used for one of the interactive teaching and learning techniques. This global view is tested among the freshmen. They were asked a 'yes', 'no' question to identify whether they are using blogs/wikis etc for accessing and posting information. Only 29 (20.7\%) respondents responded that they are using whilst 106 (75.7\%) do not use.

\section{What Net Generation Really Want?}

Preferences of students regarding library collection were encountered at first. Majority respondents $96(68.6 \%)$ use print books and journals whilst very few of them e-books and e-journals, CDs and other audio visual materials at present (table 6).

Table 6: Usage of library materials

\begin{tabular}{l|llll}
\hline Description & Frequency & Percent & ValidPercent & $\begin{array}{l}\text { Cumulative } \\
\text { Percent }\end{array}$ \\
\hline Valid & 4 & 2.9 & 2.9 & 2.9 \\
Printbooks\&joumals & 96 & 68.6 & 68.6 & 71.4 \\
E-books\&e- journals & 9 & 6.4 & 6.4 & 77.9 \\
CDs & 7 & 5.0 & 5.0 & 82.9 \\
Audiovisual materials & 11 & 7.9 & 7.9 & 90.7 \\
other & 13 & 9.3 & 9.3 & 100.0 \\
\hline Total & $\mathbf{1 4 0}$ & $\mathbf{1 0 0 . 0}$ & $\mathbf{1 0 0 . 0}$ & \\
\hline
\end{tabular}

The usage of print materials may be higher due to the availability of volume of print materials might be highest in their libraries. However 114 (81.4\%) respondents prefer electronic materials than print materials.

Further they were asked the type of information they wish to access (see table 7). Five options were given as Multimedia, Graphics, Textual information, Music and Other. Responses show that highest number of students prefer multimedia information whilst considerable number of students $39(27.9 \%)$ like textual information. Some of them like graphics, music and other types of information. 
Journal of the University Librarians Association, Sri Lanka, Vol. 16, Issue 2, July 2012

Table 7: Preferences of students towards type of materials

\begin{tabular}{l|lll}
\hline Description & Frequency & Percent & Valid Percent \\
\hline Valid & 1 & .7 & .7 \\
Multimedia & 68 & 48.6 & 48.6 \\
Graphics & 6 & 4.3 & 4.3 \\
Textual information & 39 & 27.9 & 27.9 \\
Music & 2 & 1.4 & 1.4 \\
Other & 14 & 10.0 & 10.0 \\
noanswer & 10 & 7.1 & 7.1 \\
\hline Total & 140 & 100.0 & 100.0 \\
\hline
\end{tabular}

\section{Conclusion}

Though majority students now use print materials there is a tendency to move to eresources. Digital content is preferred by these students. More than half of the respondents prefer multimedia information while only a quarter of them prefer textual information. Majority students approach the library first to solve an information problem, but among the search engines they prefer 'Google' best. Students are comfortable in asking help from librarians, but many wish to establish regular help hours. Mainly they wish to communicate with librarian directly, while some of them require e-mail, Face book and instant messaging. Though majority use internet, they do not use OPAC. Nearly $2 / 3$ of the respondents do not use wikis blogs etc.

\section{Recommendations}

Designing webpage according to preferred style of Net Generation is necessary. Information can be displayed in graphics and visual cues. Library web pages should be updated on a regular periodicity. Libraries can create blogs on valuable information resources. It will help to exchange ideas. E-mail reference services and chat can be created to close the gap between librarian and information seekers. Librarians can help students via help-desk, instant messaging, e-mail, chat or ask a librarian service from the 
Journal of the University Librarians Association, Sri Lanka, Vol. 16, Issue 2, July 2012

website. The ceiling should be eradicated. Libraries should initiate action to collect more electronic resources. Training on online catalogues and databases, Web 2.0 is also necessary. Another important factor is; these students are interested in multi media. They like virtual information, music, and games especially animated 3D environment. Digital content is preferred by these students. Therefore, libraries should find ways to develop their system of information access. This could be user friendly, approachable and integrate to quality other resources. Librarians should link the students to Library web pages, OPAC, licensed databases and e-journals.

\section{Further research}

More research is required to compare the status with other university students. This research should be extended to $2^{\text {nd }}, 3^{\text {rd }}$ and $4^{\text {th }}$ year students to identify their requirements. Social researchers of Sri Lanka can study the ethics and responsibilities, moral characters and behaviours of the NG.

\section{References}

Berk, A.R. (2009). Teaching strategies for the Net Generation. Transformative Dialogues: Teaching \& Learning Journal, 3 (2).

Clarke,T. and Clarke, E. (2009). Born digital? Pedagogy and computer-assisted learning. Education + Training, 51(5/6), 96-407. Retrieved from: http://www.emeraldinsght.com

Clarke, T. (2009). Computer assisted collaborative learning: the new generation of simulations and social computing in the business curriculum. Education + Training, 51(5/6). Retrieved from: http://www.emeraldinsght.com.

Doiron, R. and Asselin, M. (2010). Exploring a new learning landscape in tertiary education. New Library World, 12(5/6), 222-235.

Ferebee, S. and davis J. W. (2011). Persuading Library use in technologically structured individuals. Library Hi-Tech, 29(40), 586-604. Retrieved from: http://www.emeraldinsght.com.

Ismail, L. (2010). What net generation students really want: determine library helpseeking preferences of undergraduates. Reference Services Review, 38(1). 
Journal of the University Librarians Association, Sri Lanka, Vol. 16, Issue 2, July 2012

Retrieved from: http://www.emeraldinsght.com

Kotler, P. (1975). Marketing for Non profit Organizations. Prent. Hall, Englewood, Cliffs, NJ.

Lippincott, J. K. (2005). Net generation students and libraries, In Oblinger, D. G.and Oblinger J.L.eds. Educating the Net generation. Retrieved from: www.educause.edu/educatingthenetgen/

Lippincott, J.K. (2010). Information commons: meeting millennials' needs. Journal of Library Administration, 50(1).

Mi. Jia and Nesta, F. (2006). Marketing library services to the Net generation. Library Management, 27(6/7), 67-76464. Retrieved from: http://www.emeraldinsght.com.

Oblinger, D. and Oblinger J. ( 2005). Is it age or IT: first step toward understanding the Net generation in Oblinger, D. G.and Oblinger J.L.eds. Educating the Net generation. Retrieved from: www.educause.edu/educatingthenetgen/

Oblinger, D. (2003). Boomers and Gen-Xers, Millennials: understanding the new students. Retrieved from: www.educause.edu

Prensky, M. (2001). Digital Natives, digital immigrants. On the Horizon, 9(5).

Sarasinghe, S. (2010). Economic development in post-war Sri Lanka: challenging but rewarding task, 3rd, May, Sunday Observer

Shaw S. And Fairhurst D. (2008). Engaging a new generation of graduates. Education + Training, 50(5), 366-378. Retrieved from: http://www.emeraldinsght.com

Skiba, D. J. and Barton A. J. (2006). Adapting your teaching to accommodate the net generation of learners. The online journal of issues in Nursing, 11(2). Retrieved from: http://www.nursingworld.org

\section{Acknowledgements}

Ms.Shrikandaluxmy Arulanantham, Librarian and Mr. Ketheswaran, Asst. librarian from University of Jaffna and Mr. Santharuban and Mr. Ravi from Eastern University Mr. Haleem, Miss. Akmal Jahan and Mr. Sajeer from South Eastern University for assisting in Data Collection. 